\title{
Impact of antenatal oxytocin infusion on neonatal respiratory morbidity associated with elective cesarean section
}

Ibrahim Abdelazim ${ }^{1,2}$, Mohamed M. M. Farghali' ${ }^{1}$, Assem A. M. Elbiaa ${ }^{1}$, Khaled M. Abdelrazak ${ }^{1}$, Mohamed Hussain ${ }^{1}$, Amr H. Yehia ${ }^{1}$, Mona Rashad ${ }^{1}$

\section{'Department of Obstetrics and Gynecology, Ain Shams University, Cairo, Egypt ${ }^{2}$ Department of Obstetrics and Gynecology, Ahmadi Hospital, Kuwait}

Submitted: 19 March 2015

Accepted: 13 June 2015

Arch Med Sci 2017; 13, 3: 629-634

DOI: https://doi.org/10.5114/aoms.2017.67292

Copyright $\odot 2017$ Termedia \& Banach

\section{Abstract}

Introduction: This study was designed to estimate respiratory morbidity associated with elective cesarean section (ECS) and to determine the effect of antenatal oxytocin exposure on this morbidity.

Material and methods: Nine hundred and sixty-five neonates $\geq 37$ weeks' gestation delivered by cesarean section during 1 year were included in this retrospective study and classified into two groups according to oxytocin exposure before cesarean deliveries. Respiratory morbidity for each group was recorded and statistically analyzed.

Results: Transient tachypnea of newborn (TTN) was significantly more frequent in group II (ECS group) than in group I (cesarean section after oxytocin exposure) (8.19\% vs. $2.92 \%$; respectively, $p=0.0006)$. Mechanical ventilation, continuous positive airway pressure (CPAP) and oxygen therapy were significantly more frequent in group II than in group I $(1.78 \%, 2.14 \%$ and $4.28 \%$ versus $0.44 \%, 0.58 \%$ and $1.46 \%$, respectively; $p=0.039$, and $p=0.033$ and $p=0.009$, respectively). The number of newborns admitted to the neonatal unit and neonatal intensive care unit (NICU) was significantly higher in group II than in group I (6.41\% and $2.14 \%$ vs. $2.05 \%$ and $0.58 \%$, respectively; $p=0.001$ and $p=0.033$, respectively). Surfactant, fluid therapies and parenteral nutrition were significantly more frequent in group II than in group I $(2.14 \%, 4.28 \%$ and $2.49 \%$ vs. $0.15 \%, 1.46 \%$ and $0.73 \%$, respectively; $p=0.001, p=0.009$ and $p=0.02$, respectively).

Conclusions: Neonatal respiratory morbidity associated with ECS significantly decreased after antenatal oxytocin exposure. A significant reduction of neonatal respiratory morbidity would be achieved if ECS were performed after 39 weeks' gestation.

Key words: oxytocin, neonatal, respiratory, morbidity, elective cesarean sections.

\section{Introduction}

The percentage of newborns delivered by cesarean section has risen in recent years, reaching $29.6 \%$ in Kuwait, more than $30 \%$ in the United States and United Kingdom (UK), 19.31\% in Italy and as high as 48\% in Brazil. Cesarean section rates have increased rapidly even among low risk women with a full-term singleton infant in vertex presentation [1-7].

Previous studies documented high incidence of respiratory distress and neonatal intensive care unit (NICU) admissions for infants delivered

\author{
Corresponding author: \\ Ibrahim Abdelazim MD \\ Department of Obstetrics \\ and Gynecology \\ Ahmadi Hospital \\ 61008 Kuwait \\ Phone: +965-66551300 \\ E-mail:dr.ibrahimanwar@ \\ gmail.com
}


by cesarean section before the onset of spontaneous labor [8-21].

A significant number of term infants are delivered by elective cesarean section (ECS) admitted to the NICU each year in the United States with transient tachypnea of newborn (TTN), respiratory distress syndrome (RDS) and severe persistent pulmonary hypertension of newborn (PPHN) [22-28].

Infants delivered by ECS are at higher risk of TTN (RDS type II, wet lung syndrome), RDS and PPHN [28].

The timing of an ECS is critical; many authors have concluded that respiratory morbidity following ECS is inversely related to gestational age at ECS and a significant reduction of neonatal respiratory morbidity would be achieved if ECS were performed after 39 weeks' gestation [22, 24, 28].

Physiologic events in the last few weeks of pregnancy and the onset of spontaneous labor are usually associated with changes in maternal and fetal hormonal milieu and clearance of fetal lung fluid. Clearance of fetal lung fluid is crucial for gas exchange and neonatal transition, and mediated in large part by trans-epithelial sodium reabsorption through amiloride-sensitive sodium channels in the alveolar epithelial cells [29-31].

Failure of lung clearance is associated with neonatal respiratory difficulty, NICU admission, mechanical ventilation and surfactant therapy. Preventive and therapeutic strategies should be developed to reduce respiratory morbidity and to improve neonatal outcomes after ECS. Antenatal oxytocin exposure could be an effective preventive measure to reduce respiratory morbidity in term infants delivered by ECS. This study was designed to estimate respiratory morbidity associated with ECS and to determine the effect of antenatal oxytocin exposure on this morbidity.

\section{Material and methods}

This retrospective observational study was conducted over one year from May 2013 to May 2014 in Sabah Maternity Hospital (the biggest maternity hospital) and Ahmadi Hospital, Kuwait Oil Company (KOC), Kuwait. Women $\geq 37$ weeks' gestation delivered by cesarean section and their neonates were included in this study, and their medical records were evaluated after receiving approval of the study from the ethical committee of both hospitals and after informed consent from participants to estimate respiratory morbidity associated with ECS and to determine the effect of antenatal oxytocin exposure on this morbidity. The gestational age was calculated from the first day of the last menstrual period (LMP) and confirmed by early ultrasound scan (done before 20 weeks' gestation).

Women < 37 weeks' gestation or women with medical or obstetrical disorders affecting the neonatal outcome such as congenital fetal malformations, prolonged premature rupture of fetal membranes (PROM), intrauterine growth restriction (IUGR), intra-partum fetal distress, diabetes mellitus, preeclampsia, or genetic or metabolic disorders were excluded from this study.

Studied women and their neonates (965) were classified into two groups according to antenatal oxytocin exposure before delivery: group I - newborns exposed antenatally to oxytocin infusion $\geq 8 \mathrm{~h}$ and delivered by cesarean section; and group II - newborns not exposed to oxytocin infusion and delivered by ECS.

Maternal data collected include timing of cesarean section, whether cesarean section was done electively as scheduled or after trial of labor, relevant complications during pregnancy and reason for cesarean section. Neonatal data collected include gestational age at birth, birth weight, gender, small or large for gestational age, immediate resuscitation after delivery and Apgar scores. The following data were also collected: admission to neonatal unit and/or NICU, length of hospital stay, mortalities, respiratory disorders (hyaline membrane disease, TTN, meconium aspiration syndrome and pneumothorax), required respiratory support (continuous positive airway pressure (CPAP) or mechanical ventilation) and use of surfactants.

Neonatal morbidity data collected include birth trauma, asphyxia, hypoxic ischemic encephalopathy, intracranial hemorrhage, meconium aspiration and air leaks (pneumothorax). Also, hypoglycemia, polycythemia, sepsis (confirmed by clinical examination and cultures) [32, 33] jaundice, need for fluid therapy and parenteral nutrition were collected as neonatal morbidity data. The primary outcome in this study measures neonatal respiratory morbidity.

The typical respiratory morbidity in term newborns is TTN. The TTN was diagnosed in term babies ( $\geq 37$ weeks) if signs of respiratory distress (tachypnea, retractions, grunting, nasal flaring or mild cyanosis) started within hours after delivery with signs of wet lungs (congestion and perihilar streaking in chest $X$ rays). The TTN is usually improved after oxygen supplementation; also, symptoms and radiographic findings of TTN are transient, self-limited within the first week of life (3-4 days). Based on the clinical course and radiographic findings, TTN was confirmed when other pathologies such as pneumonia or respiratory distress syndrome were excluded.

\section{Sample size}

Sample size was calculated using Epilnfo version 6.0 , setting power at $80 \%$, significance level at 0.05 and using data from the previous study, 
which concluded that there is increased risk of neonatal respiratory morbidity after ECS [24].

\section{Statistical analysis}

Data were collected and statistically analyzed using Statistical Package for the Social Sciences (SPSS) computer software version 18 (Chicago, IL, USA). Numerical variables were presented as mean and standard deviation ( \pm SD), while categorical variables were presented as number $(n)$ and percentage (\%). Statistical analysis was performed using Student's $t$ and chi-square $\left(\chi^{2}\right)$ tests. A difference with a $p$-value $<0.05$ was considered statistically significant.

\section{Results}

Nine hundred and sixty-five (965) alive newborns were delivered by cesarean section during this study; 684 of them were delivered by emergency cesarean section after trial of labor and oxytocin infusion $\geq 8 \mathrm{~h}$ (group 1) and 281 were delivered by elective cesarean section (group II) (267 (95\%) were born after 39 weeks' gestation and 14 (5\%) were born at 38-39 weeks' gestation). There was no significant difference between the two studied groups regarding maternal age, parity, pre-labor weight, body mass index (BMI) or gestational age at time of cesarean section (Table I).

The most common indication for ECS was 2 or more previous cesarean sections (78\%), one previous cesarean section with refused trial of labor (19\%) and previous myomectomy (3\%). On the other hand, the most common indication for emergency cesarean section is failure to progress, and emergency cesarean section conducted due to fetal distress was excluded from this study. Failure to progress is due to cephalo-pelvic disproportion (58.12\%), malposition (37.64\%) and macrosomia (4.24\%).
There was no significant difference between the two studied groups regarding time of cesarean section, which was $38.15 \pm 1.03$ weeks' gestation in group I (CS after trial of labor and oxytocin infusion) and was $39.24 \pm 0.54$ weeks' in group II (ECS group) (Table I).

Cesarean section complications were recorded in $1.88 \%$ of the studied population in the form of: $0.86 \%$ wound infection, $0.27 \%$ uterine lacerations and extension of cesarean section incisions, $0.15 \%$ urinary bladder injury, $0.03 \%$ intestinal injury, $0.43 \%$ intra-partum hemorrhage requiring blood transfusion, $0.11 \%$ deep venous thrombosis and $0.03 \%$ pulmonary embolism.

There was no significant difference between the two studied groups regarding birth weight, number of small for gestational age babies, large for gestational age babies, babies with Apgar score $<5$ at $1 \mathrm{~min}$, babies with Apgar score $<5$ at 5 min and babies with cord $\mathrm{PH}<7.2(4$ (0.58\%) vs. $3(1.068 \%)$, respectively) (Table II).

The frequency of TTN was significantly higher in group II than in group I (23 (8.19\%) vs. 20 (2.92\%); respectively). The frequency of mechanical ventilation, CPAP and oxygen therapy was significantly higher in group II than in group I (5 (1.78\%), 6 (2.14\%) and 12 (4.28\%) vs. 3 (0.44\%), $4(0.58 \%)$ and $10(1.46 \%)$, respectively) (Table III).

The number of newborns admitted to the neonatal unit and NICU unit was significantly higher in group II than in group I (18 (6.41\%) and 6 (2.14\%) vs. $14(2.05 \%)$ and 4 (0.58\%), respectively). Surfactants, fluid therapies and parenteral nutrition were used significantly more often in group II than in group I (6 (2.14\%), $12(4.28 \%)$ and 7 (2.49\%) vs. 1 (0.15\%), $10(1.46 \%)$ and $5(0.73 \%)$, respectively) (Table III).

There were no cases of neonatal mortality, birth trauma, meconium aspiration, pneumothorax, neonatal sepsis, intracranial hemorrhage, perinatal asphyxia or hypoxic ischemic encephalopathy

Table I. Descriptive characteristics of two studied groups

\begin{tabular}{|c|c|c|c|}
\hline Variables & $\begin{array}{l}\text { Group I: cesarean section } \\
\text { after trial of labor and } \\
\text { oxytocin exposure } \\
(N=684)\end{array}$ & $\begin{array}{l}\text { Group II: elective } \\
\text { cesarean section } \\
\qquad(N=281)\end{array}$ & $\begin{array}{c}P \text {-value, significance } \\
\text { (95\% confidence interval) } \\
\text { Test used }(t \text { test) }\end{array}$ \\
\hline $\begin{array}{l}\text { Maternal age [years] } \\
\text { Mean } \pm \text { SD }\end{array}$ & $31.5 \pm 6.3$ & $33.7 \pm 7.2$ & $\begin{array}{c}p=0.99(>0.05), \mathrm{NS} \\
(95 \% \mathrm{Cl}:-3.2 ;-2.2 ;-1.2)\end{array}$ \\
\hline $\begin{array}{l}\text { Parity } \\
\text { Mean } \pm \text { SD }\end{array}$ & $3.1 \pm 1.4$ & $4.2 \pm 2.1$ & $\begin{array}{c}p=1(>0.05), \mathrm{NS} \\
(95 \% \mathrm{Cl}:-1.3 ;-1.1 ;-0.8)\end{array}$ \\
\hline $\begin{array}{l}\text { Pre-labor weight }[\mathrm{kg}] \\
\text { Mean } \pm \text { SD }\end{array}$ & $89.6 \pm 5.2$ & $92.1 \pm 6.5$ & $\begin{array}{c}p=1(>0.05), \mathrm{NS} \\
(95 \% \mathrm{Cl}:-3.3 ;-2.5 ;-1.6)\end{array}$ \\
\hline $\begin{array}{l}\text { Pre-labor BMI }\left[\mathrm{kg} / \mathrm{m}^{2}\right] \\
\text { Mean } \pm \mathrm{SD}\end{array}$ & $30.4 \pm 4.3$ & $32.3 \pm 5.1$ & $\begin{array}{c}p=0.99(>0.05), \mathrm{NS} \\
(95 \% \mathrm{Cl}:-2.6 ;-1.9 ;-1.2)\end{array}$ \\
\hline $\begin{array}{l}\text { Gestational age at time of } \\
\text { cesarean section [weeks] } \\
\text { Mean } \pm \text { SD }\end{array}$ & $38.15 \pm 1.03$ & $39.24 \pm 0.54$ & $\begin{array}{c}p=0(>0.05), \mathrm{NS} \\
(95 \% \mathrm{Cl}:-1.2 ;-1.09 ;-0.9)\end{array}$ \\
\hline
\end{tabular}


Table II. Neonatal outcomes in two studied groups

\begin{tabular}{|c|c|c|c|}
\hline Variables & $\begin{array}{l}\text { Group I: cesarean section } \\
\text { after trial of labor and } \\
\text { oxytocin exposure } \\
(N=684)\end{array}$ & $\begin{array}{l}\text { Group II: elective } \\
\text { cesarean section } \\
\qquad(N=281)\end{array}$ & $\begin{array}{l}P \text {-value, significance, test } \\
\text { used } \\
\text { (95\% confidence interval) }\end{array}$ \\
\hline $\begin{array}{l}\text { Gestational age at birth } \\
\text { [weeks] } \\
\text { Mean } \pm \text { SD }\end{array}$ & $38.15 \pm 1.03$ & $39.24 \pm 0.54$ & $\begin{array}{c}p=0(>0.05), N S, t \text { test } \\
(95 \% \mathrm{Cl}:-1.2 ;-1.09 ;-0.9)\end{array}$ \\
\hline $\begin{array}{l}\text { Birth weight }[\mathrm{kg}] \\
\text { Mean } \pm \mathrm{SD}\end{array}$ & $3.62 \pm 1.27$ & $3.79 \pm 1.22$ & $\begin{array}{l}p=0.2(>0.05), N S, t \text { test } \\
(95 \% \mathrm{Cl}:-0.3 ;-0.2 ; 0.001)\end{array}$ \\
\hline $\begin{array}{l}\text { Number (\%) of small for } \\
\text { gestational age babies }\end{array}$ & $8(1.17)$ & $6(2.14)$ & $p=0.2(>0.05), \mathrm{NS}, \chi^{2}$ test \\
\hline $\begin{array}{l}\text { Number (\%) of large for } \\
\text { gestational age babies }\end{array}$ & $18(2.63)$ & $12(4.27)$ & $p=0.1(>0.05), \mathrm{NS}, \chi^{2}$ test \\
\hline $\begin{array}{l}\text { Number (\%) of babies } \\
\text { with Apgar score less } \\
\text { than } 5 \text { at } 1 \mathrm{~min}\end{array}$ & $18(2.63)$ & $10(3.55)$ & $\begin{array}{c}p=0.09(>0.05), N S, \chi^{2} \text { test } \\
(95 \% \mathrm{Cl}:-0.3 ;-0.2 ; 0.001)\end{array}$ \\
\hline $\begin{array}{l}\text { Number (\%) of babies } \\
\text { with Apgar score less } \\
\text { than } 5 \text { at } 5 \text { min }\end{array}$ & $12(1.75)$ & $6(2.14)$ & $p=0.6(>0.05), \mathrm{NS}, \chi^{2}$ test \\
\hline $\begin{array}{l}\text { Number (\%) of babies } \\
\text { with cord PH less than } 7.2\end{array}$ & $4(0.58)$ & $3(1.068)$ & $p=0.4(>0.05), \mathrm{NS}, \chi^{2}$ test \\
\hline
\end{tabular}

Table III. Respiratory neonatal outcome in two studied groups

\begin{tabular}{|lccc|}
\hline Variables & $\begin{array}{c}\text { Group I: cesarean section } \\
\text { after trial of labor and } \\
\text { oxytocin exposure } \\
(N=684)\end{array}$ & $\begin{array}{c}\text { Group II: elective } \\
\text { cesarean section } \\
(N=281)\end{array}$ & $\begin{array}{c}P \text {-value, significance, } \\
\text { test used }\end{array}$ \\
\hline $\begin{array}{l}\text { Transient tachypnea of } \\
\text { newborn (TTN), } n(\%)\end{array}$ & $20(2.92)$ & $23(8.19)$ & $p=0.0006(<0.05), \mathrm{S}, \chi^{2}$ test \\
\hline $\begin{array}{l}\text { Conventional mechanical } \\
\text { ventilation, } n \text { (\%) }\end{array}$ & $3(0.44)$ & $5(1.78)$ & $p=0.039(<0.05), \mathrm{S}, \chi^{2}$ test \\
\hline $\begin{array}{l}\text { Continuous positive } \\
\text { airway pressure, } n(\%)\end{array}$ & $4(0.58)$ & $6(2.14)$ & $p=0.033(<0.05), \mathrm{S}, \chi^{2}$ test \\
\hline Oxygen therapy, $n(\%)$ & $10(1.46)$ & $12(4.28)$ & $p=0.009(<0.05), \mathrm{S}, \chi^{2}$ test \\
\hline $\begin{array}{l}\text { Neonatal unit admission, } \\
n \text { (\%) }\end{array}$ & $14(2.05)$ & $18(6.41)$ & $p=0.001(<0.05), \mathrm{S}, \chi^{2}$ test \\
\hline $\begin{array}{l}\text { Neonatal intensive care } \\
\text { unit admission, } n(\%)\end{array}$ & $4(0.58)$ & $6(2.14)$ & $p=0.033(<0.05), \mathrm{S}, \chi^{2}$ test \\
\hline Surfactant therapy, $n(\%)$ & $1(0.15)$ & $6(2.14)$ & $p=0.001(<0.05), \mathrm{S}, \chi^{2}$ test \\
\hline Fluid therapy, $n$ (\%) & $10(1.46)$ & $12(4.28)$ & $p=0.009(<0.05), \mathrm{S}, \chi^{2}$ test \\
\hline Parenteral nutrition, $n(\%)$ & $5(0.73)$ & $7(2.49)$ & $p=0.02(<0.05), \mathrm{S}, \chi^{2}$ test \\
\hline S- significant; $\chi^{2}-$ chi-square test. & & &
\end{tabular}

recorded in either studied group. One baby in group I born at 37.4 weeks with a birth weight of $2200 \mathrm{~g}$ (small for gestational age) developed necrotizing enterocolitis.

\section{Discussion}

Higher rates of mechanical ventilation, oxygen therapy, extracorporeal membrane oxygenation (ECMO) and death were reported after TTN delivered by ECS, and Roth-Kleiner et al. reported that me- chanical ventilation was dramatically high in infants who developed respiratory distress after ECS [34].

Performing ECS after 39 weeks' gestation seems to be associated with significant reduction of neonatal respiratory morbidity.

The American College of Obstetricians and Gynecologists (ACOG) Guidelines recommended scheduling ECS at 39 weeks or at spontaneous labor pains to reduce the occurrence of iatrogenic prematurity associated with ECS [22, 24, 28]. 
Other authors suggested increased risk of uterine rupture and perinatal death in mothers with previous cesarean section who went into spontaneous labor after 39 weeks $[35,36]$.

In this study, rates of TTN, mechanical ventilation, CPAP, oxygen therapy and NICU were significantly higher in group II (ECS group) than in group I (delivered by cesarean section after oxytocin exposure). In addition, surfactant, fluid therapies and parenteral nutrition were significantly more frequent in group II than in group I.

Recent obtained data from the Cesarean Section Registry maintained by the Maternal Fetal Medicine Units Network (MFMU) support previously published data showing higher incidence of respiratory distress in infants delivered by elective repeat cesarean section (ERCS) compared to those delivered vaginally after previous cesarean section (VBAC). The MFMU reported that $6.2 \%$ of infants delivered by ERCS $\geq 37$ weeks' gestation developed respiratory distress and $11.1 \%$ required NICU admission compared to $3.3 \%$ respiratory distress and $7.5 \%$ NICU admission in VBAC [30].

Physiologic event in the last few weeks of pregnancy coupled with the onset of spontaneous labor is associated with clearance of fetal lung fluid. Clearance of fetal lung fluid is crucial for gas exchange and for increase in pulmonary blood flow to match ventilation with perfusion [29-31].

Failure of these events can jeopardize neonatal transition and cause neonatal respiratory distress. Traditional explanations, which relied on "starling forces" and "vaginal squeeze", can only account for a fraction of the fluid absorption. Amiloride-sensitive sodium transport by lung epithelia through epithelial sodium channels (ENaC) has emerged as a key event in the trans-epithelial movement of alveolar fluid [37].

This study was based on the hypothesis that oxytocin had an effect on epithelial sodium channels, and in this study, oxytocin administration for $\geq 8 \mathrm{~h}$ in group I was associated with a significant reduction in respiratory morbidity compared to group II delivered by ECS.

The results of this study also explain the ACOG guidelines which recommend delaying ECS at spontaneous labor pains to take advantage of oxytocin release and its effect on $\mathrm{ENaC}$, which in turn will clear fluids from the lung and prepare it for gas exchange with subsequent reduction in neonatal respiratory morbidity. Also, the results of this study explain and support previously published data of higher incidence of respiratory distress in infants delivered by ERCS compared to those delivered vaginally after previous cesarean section reported by MFMU.

There is an urgent need for a preventive strategy that can optimize the outcome of vulnerable newborns delivered by ECS. Delaying ECS until 39 weeks' gestation seems to be the first logical steps in reducing iatrogenic prematurity and risks of respiratory morbidity, and antenatal steroids have an established role in reducing life-threatening respiratory morbidity of ECS [30].

This study was the first to explain the benefits of delaying ECS at spontaneous labor pains based on clearance of fetal lung fluid through epithelial sodium channels mediated by oxytocin. Retrospective nature was the only limitation of this study.

In conclusion, neonatal respiratory morbidities associated with ECS significantly decreased after antenatal oxytocin exposure. A significant reduction of neonatal respiratory morbidity would be achieved if ECS were performed after 39 weeks' gestation.

\section{Conflict of interest}

The authors declare no conflict of interest.

\section{References}

1. Le Ray C, Blondel B, Prunet C, Khireddine I, DeneuxTharaux C, Goffinet F. Stabilising the caesarean rate: which target population? BJOG 2015; 122: 690-9.

2. Wani RV, Abu-Hudra NM, Al-Tahir SI. Emergency peripartum hysterectomy: a 13-year review at a tertiary center in Kuwait. J Obstet Gynaecol India 2014; 64: 403-8.

3. Menacker F, Hamilton BE. Recent trends in cesarean delivery in the United States. NCHS Data Brief 2010; 35: 1-8.

4. Betrán AP, Vindevoghel N, Souza JP, Gülmezoglu AM, TorIoni MR. A systematic review of the Robson classification for caesarean section: what works, does not work and how to improve it. PLoS One 2014; 9: e97769.

5. Torloni MR, Betrán AP, Montilla P, et al. Do Italian women prefer cesarean section? Results from a survey on mode of delivery preferences. BMC Pregnancy Childbirth 2013; 13: 78.

6. Paleari L, Gibbons L, Chacón S, Ramil V, Belizán JM. Rates of caesarean sections in two types of private hospitals: restricted-access and open-access. Ginecol Obstet Mex 2012; 80: 263-9.

7. MacDorman MF, Declercq E, Menacker F, Malloy MH. Neonatal mortality for primary cesarean and vaginal births to low-risk women: application of an "intention-to-treat" model. Birth 2008; 35: 3-8.

8. Alderdice F, McCall E, Bailie C, et al. Admission to neonatal intensive care with respiratory morbidity following 'term' elective caesarean section. Ir Med J 2005; 98: 170-2.

9. Clark RH. The epidemiology of respiratory failure in neonates born at an estimated gestational age of 34 weeks or more. J Perinatol 2005; 25: 251-7.

10. Ersch J, Roth-Kleiner M, Baeckert P, Bucher HU. Increasing incidence of respiratory distress in neonates. Acta Paediatr 2007; 96: 1577-81.

11. Gerten KA, Coonrod DV, Bay RC, Chambliss LR. Cesarean delivery and respiratory distress syndrome: does labor make a difference? Am J Obstet Gynecol 2005; 193 : 1061-4. 
12. Gouyon JB, Ribakovsky C, Ferdynus C, Quantin C, Sagot P, Gouyon B; Burgundy Perinatal Network. Severe respiratory disorders in term neonates. Paediatr Perinat Epidemiol 2008; 22: 22-30.

13. Hansen AK, Wisborg K, Uldbjerg N, Henriksen TB. Elective caesarean section and respiratory morbidity in the term and near-term neonate. Acta Obstet Gynecol Scand 2007; 86: 389-94.

14. MacDorman MF, Declercq E, Menacker F, Malloy MH. Infant and neonatal mortality for primary cesarean and vaginal births to women with "no indicated risk," United States, 1998-2001 birth cohorts. Birth 2006; 33: $175-82$.

15. Macdorman MF, Declerca E, Menacker F, Malloy MH Neonatal mortality for low-risk women by method of delivery. Birth 2007; 34: 101-2.

16. Many A, Helpman L, Vilnai Y, Kupferminc MJ, Lessing JB, Dollberg S. Neonatal respiratory morbidity after elective cesarean section. J Matern Fetal Neonatal Med 2006; 19: 75-8.

17. McCourt C, Weaver J, Statham H, Beake S, Gamble J, Creedy DK. Elective cesarean section and decision-making: a critical review of the literature. Birth 2007; 34: 65-79.

18. Menacker F, Declercq E, Macdorman MF. Cesarean delivery: background, trends, and epidemiology. Semin Perinatol 2006; 30: 235-41.

19. Ross MG, Beall MH. Cesarean section and transient tachypnea of the newborn. Am J Obstet Gynecol 2006; 195: 1496-7.

20. Villar J, Carroli G, Zavaleta N, et al.; World Health Organization 2005 Global Survey on Maternal and Perinatal Health Research Group. Maternal and neonatal individual risks and benefits associated with caesarean delivery: multicentre prospective study. BMJ 2007; 335: 1025.

21. Zanardo V, Padovani E, Pittini C, Doglioni N, Ferrante A, Trevisanuto $D$. The influence of timing of elective cesarean section on risk of neonatal pneumothorax. J Pediatr 2007; 150: 252-45.

22. Dónaldsson SF, Dagbjartsson A, Bergsteinsson $H$ Hardardóttir H, Haraldsson A, Thórkelsson T. Respiratory dysfunction in infants born by elective cesarean section without labor. Laeknabladid 2007; 93: 675-9.

23. Fisler RE, Cohen A, Ringer SA, Lieberman E. Neonatal outcome after trial of labor compared with elective repeat cesarean section. Birth 2003; 30: 83-8.

24. Hansen AK, Wisborg K, Uldbjerg N, Henriksen TB. Risk of respiratory morbidity in term infants delivered by elective caesarean section: cohort study. BMJ 2008; 336 : 85-7.

25. Kolås T, Saugstad OD, Daltveit AK, Nilsen ST, Øian P. Planned cesarean versus planned vaginal delivery at term: comparison of newborn infant outcomes. Am J Obstet Gynecol 2006; 195: 1538-43.

26. Richardson BS, Czikk MJ, daSilva O, Natale R. The impact of labor at term on measures of neonatal outcome. Am J Obstet Gynecol 2005; 192: 219-26.

27. Riskin A, Abend-Weinger M, Riskin-Mashiah S, Kugelman A, Bader D. Cesarean section, gestational age, and transient tachypnea of the newborn: timing is the key. Am J Perinatol 2005; 22: 377-82.

28. Zanardo V, Simbi AK, Franzoi M, Soldà G, Salvadori A Trevisanuto D. Neonatal respiratory morbidity risk and mode of delivery at term: influence of timing of elective caesarean delivery. Acta Paediatr 2004; 93: 643-7.
29. Jain L, Dudell GG. Respiratory transition in infants delivered by cesarean section. Semin Perinatol 2006; 30: 296-304.

30. Ramachandrappa A, Jain L. Elective cesarean section: its impact on neonatal respiratory outcome. Clin Perinatol 2008; 35: 373-93.

31. Jonguitud Aguilar A. Elective caesarean: impact of evolution neonatal respiration. Ginecol Obstet Mex 2011; 79: 206-13.

32. Sadowska-Krawczenko I, Jankowska A, Kurylak A. Healthcare-associated infections in a neonatal intensive care unit. Arch Med Sci 2012; 8: 854-8.

33. Manan MM, Ibrahim NA, Aziz NA, Zulkifly HH, Al-Worafi YM, Long CM. Empirical use of antibiotic therapy in the prevention of early onset sepsis in neonates: a pilot study. Arch Med Sci 2016; 12: 603-13.

34. Roth-Kleiner M, Wagner BP, Bachmann D, Pfenninger J. Respiratory distress syndrome in near-term babies after caesarean section. Swiss Med Wkly 2003; 133: 283-8.

35. Bland RD. Loss of liquid from the lung lumen in labor: more than a simple "squeeze". Am J Physiol Lung Cell Mol Physiol 2001; 280: L602-5.

36. Jain L, Chen XJ, Ramosevac S, Brown LA, Eaton DC. Expression of highly selective sodium channels in alveolar type II cells is determined by culture conditions. Am J Physiol Lung Cell Mol Physiol 2001; 280: L646-58.

37. Bland RD. Lung epithelial ion transport and fluid movement during the perinatal period. Am J Physiol 1990; 259: L30-7. 